\title{
National beef tenderness survey - 2006: Assessment of Warner-Bratzler shear and sensory panel ratings for beef from US retail and foodservice establishments
}

\author{
K.L. Voges ${ }^{\text {a }}$, C.L. Mason ${ }^{\text {a }}$, J.C. Brooks ${ }^{\text {b }}$, R.J. Delmore ${ }^{c}$, D.B. Griffin ${ }^{\text {a }}$, D.S. Hale ${ }^{\text {a }}$, \\ W.R. Henning ${ }^{\mathrm{d}}$, D.D. Johnson ${ }^{\mathrm{e}}$, C.L. Lorenzen ${ }^{\mathrm{f}}$, R.J. Maddock ${ }^{\mathrm{g}}$, R.K. Miller ${ }^{\mathrm{a}}$, \\ J.B. Morgan ${ }^{\text {h }}$, B.E. Baird ${ }^{\text {i }}$, B.L. Gwartney ${ }^{i}$, J.W. Savell ${ }^{\text {a,* }}$ \\ ${ }^{a}$ Department of Animal Science, Texas A\&M University, 2471 TAMU, College Station, TX 77843-2471, USA \\ ${ }^{\mathrm{b}}$ Department of Animal Science, Texas Tech University, PO Box 42141, Lubbock, TX 79409, USA \\ ${ }^{\mathrm{c}}$ Department of Animal Science, California Poly Technical University, Animal Science Building 24, San Luis Obispo, CA 93407, USA \\ ${ }^{d}$ Department of Animal Science, Pennsylvania State University, 0307 AgSci and Ind Building, University Park, PA 16802, USA \\ ${ }^{\mathrm{e}}$ Department of Animal Science, University of Florida, PO Box 110910, Gainesville, FL 32611, USA \\ ${ }^{\mathrm{f}}$ Department of Food Science, University of Missouri, 256 William C. Stringer Wing, Columbia, MO 65211, USA \\ ${ }^{g}$ Department of Animal Science, South Dakota State University, 120 AnSci Complex, Brookings, SD 57007, USA \\ ${ }^{\text {h }}$ Department of Animal Science, Oklahoma State University, 10413 Animal Science, Stillwater, OK 74078, USA \\ ${ }^{i}$ National Cattlemen's Beef Association, 9110 East Nichols Avenue, Centennial, CO 80112, USA
}

\begin{abstract}
Beef from retail and foodservice establishments in 11 US cities was evaluated using Warner-Bratzler shear (WBS) and consumer evaluation panels. Postmortem aging times ranged from 3 to $83 \mathrm{~d}$ for retail and 7 to $136 \mathrm{~d}$ for foodservice with mean aging times of $22.6 \mathrm{~d}$ and $30.1 \mathrm{~d}$, respectively. For retail, the three cuts from the round - top round, bottom round, and eye of round - had the highest $(P<0.05)$ WBS values compared to cuts from the chuck, rib, and loin. Top loin steaks had the lowest $(P<0.05)$ WBS value compared to ribeye and top sirloin foodservice steaks. Retail bone-in top loin, top loin, ribeye, T-bone, and porterhouse received the highest $(P<0.05)$ ratings by consumers for overall like and like tenderness. Quality grade had little or no effect on foodservice sensory evaluations. Improvements in round tenderness are needed to increase consumer acceptability.
\end{abstract}

Keywords: Beef; Consumer panels; Warner-Bratzler Shear force; Market survey; Tenderness

\section{Introduction}

Attributes that determine beef palatability are tenderness, juiciness, and flavor. The Beef Consumer Satisfaction Study (Lorenzen et al., 1999; Neely et al., 1998, 1999; Savell et al., 1999) showed that tenderness is a major and contributing factor to consumers' perception of taste. Multiple

\footnotetext{
* Corresponding author. Tel.: +1 979845 3935; fax: +1 9798459454. E-mail address: j-savell@tamu.edu (J.W. Savell).
}

factors influence tenderness of meat, and each of these factors is backed by theories that attempt to explain how it influences tenderness. Belew, Brooks, McKenna, and Savell (2003) stated that the four general characteristics considered most important are postmortem proteolysis, intramuscular fat or marbling, connective tissue, and the contractile state of the muscle. These factors also help to explain the variation in tenderness among muscles from the same beef carcass.

The first National Beef Tenderness Survey (NBTS-1991; Morgan et al., 1991) was conducted to determine the ten- 
derness of beef in US retail cases based on Warner-Bratzler shear (WBS) force values and sensory panels. Morgan et al. (1991) focused solely on the retail sector; but with the increasing prevalence of foodservice, the 1998 Tenderness Survey (NBTS-1998) included a foodservice portion (Brooks et al., 2000). The NBTS-1998 found that retail cuts from the round still required more attention in processing and preparation to ensure acceptable tenderness; however, chuck cuts improved in tenderness. Providing a benchmark for beef palatability allows the industry to identify where improvements have been made and where tenderness issues may still exist. Thus, the objective of this survey was to determine tenderness of US beef from retail and foodservice establishments based on WBS force and consumer sensory panels.

\section{Materials and methods}

\subsection{Sampling}

Collaborators sampled 11 US cities once, during the period of January to March 2006. Cities sampled were Seattle, WA; Los Angeles, CA; San Francisco, CA; Denver, CO; Houston, TX; Chicago, IL; Kansas City, MO; Atlanta, GA; Tampa, FL; Philadelphia, PA; and New York, NY. In each city, two retail chains, representing at least onethird of total market share in their area, were sampled for product in four stores per chain. Retail chains were identified and permission was obtained to sample each store. Postfabrication times - as a measure of postmortem age - were recorded along with brand names and grades of product name. Retail cuts were shipped via overnight delivery to Texas A\&M University in insulated containers containing commercial ice packs, and were processed under refrigerated conditions $\left(2-4^{\circ} \mathrm{C}\right)$ after arrival. Steaks were removed from store packaging and all information available was recorded including brand designation, marketing claims, and package weight. Each steak was measured for external fat thickness and steak thickness, identified individually, vacuum packaged using a roll-stock packaging machine, and frozen at $-10{ }^{\circ} \mathrm{C}$. When multiple steaks were in a package, the package was considered the unit, not the steak, and thus kept together throughout the study.

The following cuts were sampled from the retail case and Universal Product Code (UPC) descriptions (Industry-Wide Cooperative Meat Identification Standards Committee., 2003) were used as the naming convention: Shoulder steak (UPC 1133); Ribeye steak, lip on, boneless (UPC 1203); Ribeye steak, lip-on, bone-in (UPC 1197); Top sirloin steak, boneless, cap off (UPC 1426); Bottom round steak (UPC 1466); Top round steak (UPC 1553); Eye of round steak (UPC 1481); Top loin steak (UPC 1404); Top loin steak, bone-in (UPC 1398); T-bone steak (UPC 1369); and Porterhouse steak (UPC 1330).

Approximately $60 \%$ of the steaks were used for consumer sensory panels and the rest were used for WBS evaluation. After freezing, steaks were assigned randomly to one of six consumer panels at collaborating universities. Steaks then were shipped in insulated containers with commercial ice packs to the designated university. Consumer sensory panels were conducted at Oklahoma State University, Texas Tech University, South Dakota State University, University of Florida, Pennsylvania State University, and Texas A\&M University.

While in each city, collaborators also sampled one foodservice facility. Each USDA (1997) quality grade that the facility portioned into steaks was evaluated. Postfabrication times were recorded, along with brand name, and grade. Steaks were shipped to Texas A\&M University as described above. The following cuts were sampled from foodservice establishments and Institutional Meat Purchase Specifications (IMPS) (USDA, 1996) descriptions were used as the naming convention: Ribeye roll steaks (IMPS 1112); Strip loin steaks, boneless (IMPS 1180); and Top sirloin butt steaks, center-cut, boneless (IM) (IMPS 1184B).

Foodservice steaks were vacuum packaged, frozen, and shipped to the University of Missouri using the same procedures as were used for the retail steaks. Approximately $60 \%$ of the steaks were used for consumer sensory panels and the rest were used for WBS evaluation.

\subsection{Shear analysis}

Steaks were thawed in a $4{ }^{\circ} \mathrm{C}$ cooler for $48 \mathrm{~h}$ before cooking. Grated, non-stick electric grills (Hamilton Beach ${ }^{\mathrm{TM}}$ Indoor/Outdoor Grill) were used to cook the retail cuts. The grills were pre-heated for $15 \mathrm{~min}$ to an approximate temperature of $177^{\circ} \mathrm{C}$. Foodservice steaks were cooked on a Garland ${ }^{\mathrm{TM}}$ gas grill that was pre-heated before cooking to obtain a surface temperature of $232^{\circ} \mathrm{C}$. All steaks were turned after reaching an internal temperature of $35^{\circ} \mathrm{C}$, removed at a final internal temperature of $70{ }^{\circ} \mathrm{C}$, and cooled approximately $4 \mathrm{~h}$ or until reaching room temperature. Internal temperature was monitored with a thermometer (Omega ${ }^{\text {TM }}$ HH501BT, Stamford, CT) using a $0.02 \mathrm{~cm}$ diameter, iron-constantan Type-T thermocouple wire.

After cooling, steaks were trimmed free of visible connective tissue to expose the muscle fiber orientation. At least six $1.3 \mathrm{~cm}$ cores were removed from each muscle. Approximately, six cores from the $M$. longissimus lumborum and four cores from the M. psoas major were used to represent the T-bone and porterhouse steaks. Cores were removed parallel to the muscle fiber orientation and sheared once, perpendicular to the muscle fibers, on a United Testing machine (United 5STM-500, Huntington Beach, CA) using an $11.3 \mathrm{~kg}$ load cell, and a Warner-Bratzler shear force attachment. The peak force $(\mathrm{N})$ needed to shear each core was recorded, and the mean for each steak was used in statistical analysis.

\subsection{Consumer panels}

Panelists ( $n=713$ ) recruited from the surrounding communities and within collaborating universities were asked 
to complete a demographic questionnaire and a consent form. Steaks were served randomly to individual panelists in sensory booths. Each consumer received two $1.27 \mathrm{~cm}$ cubes of each sample and evaluated eight random samples during the session. Samples were characterized using 10point scales for overall like $(10=$ like extremely; $1=$ dislike extremely), flavor $(10=$ like extremely; $1=$ dislike extremely $)$, beef flavor $(10=$ an extreme amount; $1=$ none at all), juiciness ( $10=$ very juicy; $1=$ not at all juicy), and tenderness $(10=$ very tender; $1=$ not at all tender $)$, and like tenderness $(10=$ like extremely; $1=$ dislike extremely $)$.

\subsection{Statistical analysis}

Before analysis, steaks were divided into groups based on the steak type for retail and foodservice and grade within steak type for foodservice. Analysis of variance was performed with SAS PROC GLM, and when significant differences occurred, means were separated using the $p$-diff option. Box Cox transformation was used to ensure normal distribution for analyses. The percentages of steaks stratified into tenderness classes (Belew et al., 2003; Shackelford, Morgan, Savell, \& Cross, 1991) were analyzed using PROC FREQ of SAS.

\section{Results}

\subsection{Postfabrication aging times}

Subprimal postfabrication times at the retail level averaged $22.6 \mathrm{~d}$ (Table 1) and the range was 3-83 d. These data are similar to those found by Morgan et al. (1991) with a range of 3-90 d and are greater than those reported by Brooks et al. (2000) with the range of 2-61 d. Bone-in ribeyes possessed the lowest percentage of boxes aged under $14 \mathrm{~d}$, whereas top rounds had the largest percentage. The mean percentage of subprimals aged under $14 \mathrm{~d}$ was 19.6 ,

Table 1

Postfabrication times (d) for subprimal cuts audited in the cold storage facilities of retail stores

\begin{tabular}{lrlrlll}
\hline Subprimal & \multicolumn{1}{c}{$n^{\mathrm{a}}$} & Mean & \multicolumn{1}{c}{ SD } & Min $^{\mathrm{b}}$ & $\mathrm{Max}^{\mathrm{c}}$ & $\%<14 \mathrm{~d}^{\mathrm{d}}$ \\
\hline Shoulder clod & 157 & 17.3 & 9.3 & 7 & 69 & 38.9 \\
Ribeye roll & 61 & 26.9 & 13.7 & 8 & 77 & 11.3 \\
Bone-in ribeye & 165 & 27.7 & 11.6 & 7 & 79 & 3.0 \\
Strip loin & 200 & 26.2 & 12.2 & 3 & 70 & 10.0 \\
Bone-in strip loin & 98 & 26.2 & 13.2 & 8 & 75 & 5.0 \\
Short loin & 163 & 23.1 & 11.9 & 5 & 83 & 16.0 \\
Top sirloin & 149 & 24.4 & 10.4 & 8 & 55 & 14.8 \\
Top round & 163 & 17.6 & 8.8 & 7 & 48 & 46.4 \\
Bottom round & 145 & 17.5 & 6.9 & 8 & 50 & 28.1 \\
Eye round & 84 & 21.4 & 7.1 & 7 & 35 & 11.8 \\
Overall & 1391 & 22.6 & 11.3 & 3 & 83 & 19.6 \\
\hline
\end{tabular}

${ }^{\text {a }} n=$ number of packages.

${ }^{\mathrm{b}}$ Min $=$ minimum value.

${ }^{\mathrm{c}} \mathrm{Max}=$ maximum value.

d $\%<14 \mathrm{~d}=$ percentage of subprimals aged less than $14 \mathrm{~d}$. which was considerably lower than the $34.1 \%$ in the NBTS-1998 (Brooks et al., 2000).

Postfabrication aging times for foodservice subprimals (Table 2) showed that the mean aging time was $30.1 \mathrm{~d}$. This is very similar to the times reported by Brooks et al. (2000) with the mean aging time being $32 \mathrm{~d}$. The shortest aging time, $7 \mathrm{~d}$, was found for some ribeyes, whereas the longest aging time, $136 \mathrm{~d}$, was observed for some strip loins. These data show a much wider range in aging time than did Brooks et al. (2000).

\subsection{Product information}

Nearly half of retail cuts were branded with a packer program, and approximately $43 \%$ of retail cuts were labeled with a store brand. External fat thickness, steak thickness, and package weight of retail cuts are presented in Table 3. Steaks originating from the round possessed less $(P<0.05)$ external fat than those originating from the beef loin (top loin, bone-in top loin, T-bone, porterhouse) and from the rib (ribeye, bone-in ribeye). Mean external fat thickness across all cuts was $0.27 \mathrm{~cm}$ (data not reported in tabular form) and supports findings from Brooks et al. (2000) who found the mean to be $0.28 \mathrm{~cm}$. Steaks fabricated from the round and chuck were cut thinner $(P<0.05)$ than those from the rib and loin. Bottom round steaks were cut the thinnest at $1.75 \mathrm{~cm}$ compared to the thickest steaks, top loin steaks, at $2.60 \mathrm{~cm}$.

Foodservice external fat thickness, steak thickness, and steak weights are reported in Table 4. Top sirloin steaks possessed less $(P<0.05)$ fat when compared to ribeyes and top loin steaks. Ribeye steaks were cut the thinnest $(P<0.05)$ at $2.66 \mathrm{~cm}$ and top sirloin steaks were the thickest $(P<0.05)$ at $3.17 \mathrm{~cm}$. Steak weights varied between steaks with the top sirloin steaks the lightest $(P<0.05)$ and ribeyes the heaviest $(P<0.05)$.

\subsection{Warner-Bratzler shear force}

WBS values for retail cuts are presented in Table 5. Bottom round steaks had the highest $(P<0.05)$ WBS value compared to all other retail cuts. Eye of round, shoulder, and top round steaks also had higher $(P<0.05)$ WBS values than the remaining retail cuts. Brooks et al. (2000)

Table 2

Postfabrication times (d) for subprimal cuts audited at the foodservice level

\begin{tabular}{llllccl}
\hline Subprimal & $n^{\mathrm{a}}$ & Mean & SD & $\operatorname{Min}^{\mathrm{b}}$ & $\operatorname{Max}^{\mathrm{c}}$ & $\%<14 \mathrm{~d}^{\mathrm{d}}$ \\
\hline Ribeye & 146 & 30.6 & 25.8 & 7 & 122 & 37.2 \\
Top loin & 140 & 41.7 & 30.3 & 11 & 136 & 29.6 \\
Top sirloin & 140 & 33.2 & 20.9 & 9 & 95 & 20.8 \\
Overall & 426 & 30.1 & 26.3 & 7 & 136 & 29.5 \\
\hline
\end{tabular}

\footnotetext{
${ }^{\mathrm{a}} n=$ number of steaks.

${ }^{\mathrm{b}} \mathrm{Min}=$ minimum value.

${ }^{\mathrm{c}}$ Max $=$ maximum value.

d $\%<14 \mathrm{~d}=$ percentage of subprimals aged less than $14 \mathrm{~d}$.
} 
Table 3

Least squares means \pm standard errors for external fat thickness, steak thickness, and package weight of retail cuts

\begin{tabular}{lrlll}
\hline Steak & $n^{\mathrm{a}}$ & External fat thickness, cm & Steak thickness, cm & Package weight, kg \\
\hline Shoulder & 79 & $0.21 \pm 0.17 \mathrm{c}$ & $2.18 \pm 0.74 \mathrm{~d}$ & $0.58 \pm 0.25 \mathrm{de}$ \\
Ribeye, lip-on, bnls & 275 & $0.32 \pm 0.19 \mathrm{e}$ & $2.49 \pm 0.58 \mathrm{f}$ & $0.43 \pm 0.17 \mathrm{~b}$ \\
Ribeye, lip-on, bone-in & 46 & $0.30 \pm 0.19 \mathrm{de}$ & $2.56 \pm 0.49 \mathrm{f}$ & $0.49 \pm 0.15 \mathrm{bc}$ \\
Top loin & 258 & $0.34 \pm 0.19 \mathrm{ef}$ & $2.60 \pm 0.59 \mathrm{f}$ & $0.44 \pm 0.20 \mathrm{~b}$ \\
Top loin, bone-in & 45 & $0.38 \pm 0.16 \mathrm{fg}$ & $2.50 \pm 0.44 \mathrm{f}$ & $0.34 \pm 0.51 \mathrm{de}$ \\
T-bone & 128 & $0.41 \pm 0.20 \mathrm{~g}$ & $2.48 \pm 0.54 \mathrm{ef}$ & $0.53 \pm 0.28 \mathrm{~cd}$ \\
Porterhouse & 90 & $0.38 \pm 0.18 \mathrm{fg}$ & $2.33 \pm 0.63 \mathrm{~d}$ & $0.55 \pm 0.16 \mathrm{~d}$ \\
Top sirloin, bnls, cap off & 218 & $0.21 \pm 0.22 \mathrm{c}$ & $2.28 \pm 0.88 \mathrm{~d}$ & $0.57 \pm 0.25 \mathrm{de}$ \\
Top round & 104 & $0.11 \pm 0.19 \mathrm{~b}$ & $1.75 \pm 0.63 \mathrm{~b}$ & $0.63 \pm 0.23 \mathrm{e}$ \\
Bottom round & 117 & $0.27 \pm 0.22 \mathrm{~d}$ & $2.00 \pm 0.86 \mathrm{bc}$ & $0.58 \pm 0.39 \mathrm{de}$ \\
Eye of round & 199 & $0.08 \pm 0.12 \mathrm{~b}$ & $<0.0001$ & $0.47 \pm 0.27 \mathrm{bc}$ \\
$P>$ F & & $<0.0001$ & $<0.0001$ & \\
\hline
\end{tabular}

Within a column, means lacking a common letter $(\mathrm{b}-\mathrm{g})$ differ $(P<0.05)$.

${ }^{\text {a }} n=$ number of steaks.

Table 4

Least squares means \pm standard errors for external fat thickness and steak thickness of foodservice cuts

\begin{tabular}{lllll}
\hline Steak & $n^{\mathrm{a}}$ & $\begin{array}{l}\text { External fat } \\
\text { thickness, cm }\end{array}$ & $\begin{array}{l}\text { Steak } \\
\text { thickness, cm }\end{array}$ & $\begin{array}{l}\text { Package } \\
\text { weight, kg }\end{array}$ \\
\hline Ribeye & 188 & $0.36 \pm 0.36 \mathrm{c}$ & $2.66 \pm 0.41 \mathrm{~b}$ & $0.34 \pm 0.03 \mathrm{~d}$ \\
Top loin & 189 & $0.36 \pm 0.16 \mathrm{c}$ & $3.02 \pm 0.50 \mathrm{c}$ & $0.33 \pm 0.04 \mathrm{c}$ \\
$\begin{array}{l}\text { Top } \\
\quad \text { sirloin }\end{array}$ & 168 & $0.11 \pm 0.20 \mathrm{~b}$ & $3.17 \pm 0.74 \mathrm{~d}$ & $0.28 \pm 0.06 \mathrm{~b}$ \\
$P>\mathrm{F}$ & & $<0.0001$ & $<0.0001$ & $<0.0001$ \\
\hline
\end{tabular}

Within a column, means lacking a common letter $(\mathrm{b}-\mathrm{d})$ differ $(P<0.05)$.

${ }^{\text {a }} n=$ number of steaks.

found WBS values for the shoulder, bottom round, and eye of round to be $29.5,49.9,41.1 \mathrm{~N}$, respectively. Morgan et al. (1991) reported WBS values for the shoulder, bottom round, and eye of round to be $39.3,43.0$, and $45.8 \mathrm{~N}$, respectively. However, in the NBTS-1991, the steaks were braised to an internal temperature of $85^{\circ} \mathrm{C}$, compared to $70{ }^{\circ} \mathrm{C}$ in our study and the NBTS-1998. Top loin, bonein strip, bone-in ribeye, T-bone and porterhouse steaks had the lowest WBS values found in our study. Brooks

Table 5

Least squares means and standard errors (SE) for Warner-Bratzler shear values $(\mathrm{N})$ of retail steaks

\begin{tabular}{llll}
\hline Steak & $n^{\mathrm{a}}$ & Mean, N & $\mathrm{SE}$ \\
\hline Shoulder & 23 & $27.8 \mathrm{e}$ & 1.1 \\
Ribeye, lip-on, bnls & 81 & $23.2 \mathrm{~cd}$ & 0.6 \\
Ribeye, lip-on, bone-in & 19 & $21.2 \mathrm{bc}$ & 1.2 \\
Top loin & 75 & $20.8 \mathrm{~b}$ & 0.6 \\
Top loin, bone-in & 15 & $21.0 \mathrm{bc}$ & 1.4 \\
T-bone & 48 & $22.3 \mathrm{bc}$ & 0.8 \\
Porterhouse & 32 & $22.8 \mathrm{bc}$ & 1.0 \\
Top sirloin, bnls, cap off & 70 & $24.6 \mathrm{~d}$ & 0.6 \\
Top round & 39 & $29.6 \mathrm{e}$ & 0.9 \\
Bottom round & 27 & $36.0 \mathrm{~g}$ & 1.0 \\
Eye of round & 29 & $33.2 \mathrm{f}$ & 1.0 \\
$P>$ F & & $<0.0001$ & \\
\hline
\end{tabular}

Means lacking a common letter $(\mathrm{b}-\mathrm{g})$ differ $(P<0.05)$.

${ }^{\mathrm{a}} n=$ number of packages. et al. (2000) reported the T-bone and porterhouse steaks to have the lowest WBS values in the NBTS-1998.

Least squares means for WBS values of foodservice cuts are presented in Table 6. Top loin steaks had the lowest $(P<0.05)$ WBS value compared to ribeye and top sirloin steaks. All cuts had very low WBS values.

Tenderness categories developed by Belew et al. (2003) and Shackelford et al. (1991) are based on WBS values and were used to determine percentages of retail cuts that fell into each group (Table 7). Top round, bottom round, and eye round steaks were the only cuts shown to have WBS values over $45.1 \mathrm{~N}$. These percentages are much lower than those found by Brooks et al. (2000) and Morgan et al. (1991). Our study had lower numerical percentages for all cuts exceeding $38.3 \mathrm{~N}$ WBS values. Consistent cooking methods allowed for the comparison of tenderness between cuts sampled in 2006 and 1998. However, using a single cooking method did not allow for the use of other methods that may optimize the palatability of cuts that contain higher connective tissue levels (Brooks et al., 2000). Table 8 illustrates the foodservice steaks stratified into tenderness categories. Top loin steaks had the highest numerical percentage of steaks in the "very tender" category, WBS $<31.4 \mathrm{~N}$. Top sirloin steaks comprised the greatest numerical percentage of steaks that were classified as "tender" and "tough." Least squares means for WBS values of foodservice cuts stratified by grade are presented in Table 9. No significant differences were found across grades for WBS values. These data concur with Brooks

Table 6

Least squares means and standard errors (SE) for Warner-Bratzler shear values $(\mathrm{N})$ of foodservice steaks

\begin{tabular}{lrll}
\hline Steak & $n^{\mathrm{a}}$ & Mean, N & SE \\
\hline Ribeye & 118 & $27.0 \mathrm{c}$ & 0.5 \\
Top loin & 119 & $21.9 \mathrm{~b}$ & 0.5 \\
Top sirloin & 99 & $27.4 \mathrm{c}$ & 0.6 \\
$P>$ F & & $<0.0001$ & \\
\hline
\end{tabular}

Means lacking a common letter (b and c) differ $(P<0.05)$.

${ }^{\mathrm{a}} n=$ number of steaks. 
Table 7

Percentage distribution of retail steaks stratified into tenderness categories

\begin{tabular}{|c|c|c|c|c|}
\hline Steak & $\begin{array}{l}\text { "Very } \\
\text { Tender" } \\
\text { WBS } \\
<31.4 \mathrm{~N}\end{array}$ & $\begin{array}{l}\text { "Tender" } \\
31.4 \mathrm{~N} \\
<\mathrm{WBS} \\
<38.3 \mathrm{~N}\end{array}$ & $\begin{array}{l}\text { "Intermediate" } \\
38.3 \mathrm{~N} \\
<\mathrm{WBS} \\
<45.1 \mathrm{~N}\end{array}$ & $\begin{array}{l}\text { "Tough' } \\
\text { WBS }> \\
45.1 \mathrm{~N}\end{array}$ \\
\hline Shoulder & 69.6 & 30.4 & & \\
\hline $\begin{array}{l}\text { Ribeye, } \\
\quad \text { lip-on, bnls }\end{array}$ & 95.1 & 4.9 & & \\
\hline $\begin{array}{l}\text { Ribeye, } \\
\quad \text { lip-on, bone-in }\end{array}$ & 100.0 & & & \\
\hline Top loin & 98.7 & 1.3 & & \\
\hline Top loin, bone-in & 100.0 & & & \\
\hline T-bone & 97.0 & & 2.1 & \\
\hline Porterhouse & 93.8 & 6.3 & & \\
\hline $\begin{array}{l}\text { Top sirloin, bnls, } \\
\text { cap off }\end{array}$ & 87.1 & 12.9 & & \\
\hline Top round & 61.5 & 25.6 & 10.3 & 2.6 \\
\hline Bottom round & 22.2 & 48.2 & 18.5 & 11.1 \\
\hline Eye of round & 34.5 & 55.2 & 6.9 & 3.5 \\
\hline
\end{tabular}

Table 8

Least squares means for Warner-Bratzler shear (WBS) force and the percentage distribution of foodservice steaks stratified into tenderness categories

\begin{tabular}{|c|c|c|c|c|}
\hline Steak & $\begin{array}{l}\text { "Very } \\
\text { Tender" } \\
\text { WBS } \\
<31.4 \mathrm{~N}\end{array}$ & $\begin{array}{l}\text { "Tender" } \\
31.4 \mathrm{~N} \\
<\mathrm{WBS} \\
<38.3 \mathrm{~N}\end{array}$ & $\begin{array}{l}\text { "Intermediate" } \\
38.3 \mathrm{~N}<\text { WBS } \\
<45.1 \mathrm{~N}\end{array}$ & $\begin{array}{l}\text { "Tough" } \\
\text { WBS } \\
>45.1 \mathrm{~N}\end{array}$ \\
\hline Ribeye & 81.4 & 12.7 & 5.1 & 0.9 \\
\hline Top loin & 96.6 & 3.4 & & \\
\hline Top sirloin & 73.7 & 22.2 & 2.0 & 2.0 \\
\hline
\end{tabular}

et al. (2000) for the top loin steaks; however, differences were found for ribeye and top sirloin steaks in the NBTS-1998.

\subsection{Retail consumer sensory evaluations}

Consumer demographic information is presented in Table 10 for retail and foodservice consumer panelists. Information obtained from collaborating universities was combined and presented as retail data. Least squares means for sensory panel ratings for retail steaks are presented in Table 11. The bone-in top loin, top loin, ribeye, T-bone, and porterhouse received the highest $(P<0.05)$ ratings by consumers for overall like and like tenderness.
Table 10

Age, income, gender, and beef use of consumers that participated in the retail (universities combined) and foodservice sensory panels

\begin{tabular}{lllll}
\hline Item & \multicolumn{2}{l}{ Retail } & & \multicolumn{2}{l}{ Foodservice } \\
\cline { 2 - 3 }$n n$ & & & $n$ & $\%$ \\
\hline 599 & & 114
\end{tabular}

\begin{tabular}{|c|c|c|c|c|}
\hline \multicolumn{5}{|l|}{ Age, $y r$} \\
\hline$<20$ & 14 & 2.3 & & \\
\hline $20-29$ & 206 & 34.4 & 24 & 21.1 \\
\hline $30-39$ & 101 & 16.9 & 17 & 14.9 \\
\hline $40-49$ & 119 & 19.9 & 42 & 36.8 \\
\hline $50-59$ & 106 & 17.7 & 18 & 15.8 \\
\hline 60 and over & 53 & 8.9 & 13 & 11.4 \\
\hline \multicolumn{5}{|l|}{ Income, US\$ } \\
\hline$<20,000$ & 146 & 24.5 & & \\
\hline $20,000-29,000$ & 59 & 9.9 & & \\
\hline $30,000-39,000$ & 81 & 13.6 & & \\
\hline $40,000-49,000$ & 59 & 9.9 & & \\
\hline $50,000-59,000$ & 80 & 13.5 & & \\
\hline 60,000 and over & 170 & 28.6 & & \\
\hline \multicolumn{5}{|l|}{ Gender } \\
\hline Male & 272 & 45.4 & 54 & 47.4 \\
\hline Female & 327 & 54.6 & 60 & 52.6 \\
\hline \multicolumn{5}{|l|}{ Working status } \\
\hline Not employed & 51 & 8.5 & 12 & 10.5 \\
\hline Full-time & 374 & 62.5 & 79 & 69.3 \\
\hline Part-time & 45 & 7.5 & 6 & 5.3 \\
\hline Student & 128 & 21.4 & 17 & 14.9 \\
\hline \multicolumn{5}{|l|}{ Ethnicity } \\
\hline Caucasian & 520 & 87 & 104 & 91.2 \\
\hline Black & 27 & 4.5 & 4 & 3.5 \\
\hline Hispanic & 25 & 4.2 & 1 & 0.9 \\
\hline American Indian & 7 & 1.2 & 1 & 0.9 \\
\hline Asian or Pacific Islander & 19 & 3.2 & 4 & 3.5 \\
\hline \multicolumn{5}{|l|}{ Household } \\
\hline 1 & 127 & 21.2 & & \\
\hline 2 & 204 & 34.1 & & \\
\hline 3 & 110 & 18.4 & & \\
\hline 4 & 115 & 19.2 & & \\
\hline 5 & 31 & 5.2 & & \\
\hline 6 or $>$ & 12 & 2 & & \\
\hline
\end{tabular}

Round cuts, including top round, bottom round, and eye round steaks, received the lowest $(P<0.05)$ sensory ratings for overall like and like tenderness. For tenderness evaluation, the bone-in top loin and porterhouse steaks received among the highest $(P<0.05)$ ratings from consumers,

Table 9

Least squares means \pm standard errors for Warner-Bratzler shear values $(\mathrm{N})$ of foodservice steaks stratified by USDA grade

\begin{tabular}{|c|c|c|c|c|c|c|c|c|c|}
\hline \multirow[t]{3}{*}{ Steak } & \multicolumn{8}{|c|}{ Group } & \multirow[t]{3}{*}{$P>\mathrm{F}$} \\
\hline & \multicolumn{2}{|c|}{ Prime } & \multicolumn{2}{|c|}{ Top Choice } & \multicolumn{2}{|c|}{ Low Choice } & \multicolumn{2}{|c|}{ Select } & \\
\hline & $\overline{n^{\mathrm{a}}}$ & & $n^{\mathrm{a}}$ & & $\overline{n^{\mathrm{a}}}$ & & $n^{\mathrm{a}}$ & & \\
\hline Top loin & 49 & $20.3 \pm 0.9$ & 42 & $21.8 \pm 1.0$ & 56 & $23.3 \pm 0.8$ & 35 & $22.7 \pm 1.1$ & 0.1 \\
\hline Top sirloin & 35 & $26.7 \pm 1.5$ & 42 & $27.6 \pm 1.4$ & 49 & $26.8 \pm 1.2$ & 42 & $28.2 \pm 1.4$ & 0.8 \\
\hline
\end{tabular}

${ }^{\mathrm{a}} n=$ number of steaks. 
Table 11

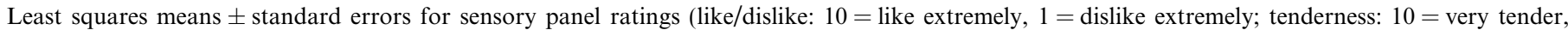
$1=$ not tender at all; juiciness: $10=$ very juicy, $1=$ not at all juicy; flavor: $10=$ extreme amount, $1=$ none at all) for retail steaks

\begin{tabular}{|c|c|c|c|c|c|c|c|c|}
\hline Steak & $n^{\mathrm{a}}$ & $\begin{array}{l}\text { Overall like/ } \\
\text { dislike }\end{array}$ & $\begin{array}{l}\text { Like/dislike } \\
\text { tenderness }\end{array}$ & Tenderness & $\begin{array}{l}\text { Like/dislike } \\
\text { flavor }\end{array}$ & Beef flavor & $\begin{array}{l}\text { Like/dislike } \\
\text { juiciness }\end{array}$ & Juiciness \\
\hline Shoulder & 23 & $5.6 \pm 0.1 \mathrm{~d}$ & $5.7 \pm 0.2 \mathrm{c}$ & $6.0 \pm 0.2 \mathrm{~d}$ & $5.7 \pm 0.2 \mathrm{c}$ & $5.8 \pm 0.2 \mathrm{~cd}$ & $5.8 \pm 0.1 \mathrm{e}$ & $5.4 \pm 0.02 \mathrm{e}$ \\
\hline Ribeye, lip-on, bnls & 81 & $6.5 \pm 0.0 \mathrm{bc}$ & $6.8 \pm 0.1 b$ & $6.9 \pm 0.1 b c$ & $6.4 \pm 0.1 b$ & $6.4 \pm 0.1 b$ & $6.4 \pm 0.04 \mathrm{c}$ & $6.2 \pm 0.1 \mathrm{c}$ \\
\hline Ribeye, lip-on, bone-in & 19 & $5.9 \pm 0.2 \mathrm{~cd}$ & $6.2 \pm 0.3 c$ & $6.4 \pm 0.4 \mathrm{~cd}$ & $6.3 \pm 0.3 b c$ & $6.4 \pm 0.4 b c$ & $6.1 \pm 0.1 \mathrm{cde}$ & $5.9 \pm 0.04 \mathrm{cde}$ \\
\hline Top loin & 75 & $6.5 \pm 0.1 b c$ & $6.9 \pm 0.1 b$ & $6.9 \pm 0.1 b c$ & $6.5 \pm 0.1 b$ & $6.6 \pm 0.1 b$ & $6.2 \pm 0.1 \mathrm{~cd}$ & $6.1 \pm 0.1 \mathrm{~cd}$ \\
\hline Top loin, bone-in & 15 & $6.9 \pm 0.2 b$ & $7.2 \pm 0.3 b$ & $7.4 \pm 0.4 b$ & $6.6 \pm 0.3 b$ & $6.5 \pm 0.4 b$ & $7.3 \pm 0.2 b$ & $7.0 \pm 0.1 b$ \\
\hline T-bone & 48 & $6.6 \pm 0.1 b$ & $6.9 \pm 0.1 b$ & $7.0 \pm 0.2 b c$ & $6.5 \pm 0.1 b$ & $6.4 \pm 0.2 b$ & $6.3 \pm 0.1 \mathrm{~cd}$ & $6.0 \pm 0.1 \mathrm{~cd}$ \\
\hline Porterhouse & 32 & $6.5 \pm 0.1 b c$ & $7.1 \pm 0.1 b$ & $7.1 \pm 0.2 b$ & $6.4 \pm 0.1 b$ & $6.5 \pm 0.2 b$ & $6.1 \pm 0.1 \mathrm{de}$ & $5.8 \pm 0.03 \mathrm{de}$ \\
\hline Top sirloin, bnls, cap off & 70 & $5.5 \pm 0.1 \mathrm{~d}$ & $5.7 \pm 0.1 \mathrm{c}$ & $5.9 \pm 0.1 \mathrm{~d}$ & $5.7 \pm 0.1 \mathrm{c}$ & $6.1 \pm 0.1 \mathrm{c}$ & $5.5 \pm 0.1 \mathrm{e}$ & $5.3 \pm 0.02 \mathrm{e}$ \\
\hline Top round & 39 & $4.8 \pm 0.7 \mathrm{e}$ & $4.5 \pm 0.1 \mathrm{~d}$ & $4.6 \pm 0.2 \mathrm{e}$ & $5.3 \pm 0.1 \mathrm{~d}$ & $5.5 \pm 0.2 \mathrm{~d}$ & $4.7 \pm 0.1 \mathrm{f}$ & $4.5 \pm 0.03 f$ \\
\hline Bottom round & 27 & $4.3 \pm 0.1 \mathrm{f}$ & $3.9 \pm 0.2 \mathrm{e}$ & $4.1 \pm 0.2 \mathrm{f}$ & $4.9 \pm 0.2 \mathrm{de}$ & $5.5 \pm 0.2 \mathrm{~d}$ & $4.6 \pm 0.1 \mathrm{f}$ & $4.4 \pm 0.03 f$ \\
\hline Eye of round & 29 & $4.6 \pm 0.1 \mathrm{ef}$ & $4.5 \pm 0.1 \mathrm{~d}$ & $4.6 \pm 0.2 \mathrm{e}$ & $4.9 \pm 0.1 \mathrm{e}$ & $5.1 \pm 0.2 \mathrm{e}$ & $4.4 \pm 0.1 \mathrm{f}$ & $4.2 \pm 0.03 \mathrm{f}$ \\
\hline$P>\mathrm{F}$ & & $<0.0001$ & $<0.0001$ & $<0.0001$ & $<0.0001$ & $<0.0001$ & $<0.0001$ & $<0.0001$ \\
\hline
\end{tabular}

Within a column, means lacking a common letter $(\mathrm{b}-\mathrm{f})$ differ $(P<0.05)$.

a $n=$ number of packages.

whereas the cuts from the round received the lowest $(P<0.05)$ scores. Steaks from the rib and loin - ribeye, bone-in ribeye, top loin, bone-in top loin, T-bone, and porterhouse steaks - received the highest ratings for like flavor

Table 12

Least squares means \pm standard errors for sensory panel ratings (like/ dislike: $10=$ like extremely, $1=$ dislike extremely; tenderness: $10=$ very tender, $1=$ not tender at all; Juiciness: $10=$ very juicy, $1=$ not at all juicy; flavor: $10=$ extreme amount, $1=$ none at all) for foodservice steaks

\begin{tabular}{llllr}
\hline Sensory rating & $\begin{array}{l}\text { Ribeye } \\
\text { steak }\end{array}$ & $\begin{array}{l}\text { Top loin } \\
\text { steak }\end{array}$ & $\begin{array}{l}\text { Top sirloin } \\
\text { steak }\end{array}$ & $P>\mathrm{F}$ \\
\hline$n^{\mathrm{a}}$ & 188 & 182 & 168 & \\
$\begin{array}{l}\text { Overall like/dislike } \\
\text { Like/dislike }\end{array}$ & $7.0 \pm 0.5 \mathrm{~b}$ & $6.8 \pm 0.5 \mathrm{~b}$ & $6.3 \pm 0.5 \mathrm{c}$ & 0.0006 \\
$\quad$ tenderness & $7.0 \pm 0.4 \mathrm{~b}$ & $7.1 \pm 0.4 \mathrm{~b}$ & $6.1 \pm 0.4 \mathrm{c}$ & $<0.0001$ \\
$\begin{array}{l}\text { Tenderness } \\
\text { Like/dislike flavor }\end{array}$ & $7.1 \pm 0.7 \mathrm{~b}$ & $7.2 \pm 0.7 \mathrm{~b}$ & $6.5 \pm 0.7 \mathrm{c}$ & $<0.0001$ \\
$\begin{array}{l}\text { Beef flavor } \\
\text { Like/dislike }\end{array}$ & $6.7 \pm 0.5$ & $6.8 \pm 0.8$ & $6.6 \pm 0.8$ & 0.1281 \\
$\quad$ juiciness & $6.2 \pm 0.1 \mathrm{~b}$ & $6.3 \pm 0.1 \mathrm{~b}$ & $5.6 \pm 0.1 \mathrm{c}$ & 0.0015 \\
Juiciness & $5.9 \pm 0.1 \mathrm{~b}$ & $6.0 \pm 0.1 \mathrm{~b}$ & $5.2 \pm 0.1 \mathrm{c}$ & 0.0003 \\
\hline
\end{tabular}

Within a row, means lacking a common letter (b and c) differ $(P<0.05)$.

${ }^{\text {a }} n=$ number of steaks. and beef flavor, whereas the steaks from the round - top round, bottom round, and eye round steaks - were given the lowest marks by consumers. The bone-in top loin steak received the highest $(P<0.05)$ juiciness and juiciness desirability ratings and steaks from the round received the lowest. Overall, the bone-in top loin steak received the highest ratings across all sensory attributes.

\subsection{Foodservice consumer sensory evaluations}

Least squares means and standard errors for sensory panel ratings of foodservice ribeye steaks are found in Table 12. Ribeye and top loin steaks received higher $(P<0.05)$ ratings for overall like, like tenderness, tenderness, like juiciness, and juiciness when compared to top sirloin steaks. No differences were found for like flavor and beef flavor. Table 13 displays the least squares means and standard errors for sensory panel ratings for foodservice ribeye steaks stratified into grades. USDA Select ribeye steaks received higher $(P<0.05)$ scores for like flavor than did the other grades. For all other attributes, no differences were found across quality grade groups supporting the findings of Brooks et al. (2000). Sensory panel rating means

Table 13

Least squares means \pm standard errors for sensory panel ratings (Like/dislike: $10=$ like extremely, $1=$ dislike extremely; Tenderness: $10=$ very tender, $1=$ not tender at all; Juiciness: $10=$ very juicy, $1=$ not at all juicy; Flavor: $10=$ extreme amount, $1=$ none at all) for foodservice ribeye steaks

\begin{tabular}{|c|c|c|c|c|c|}
\hline \multirow[t]{2}{*}{ Sensory rating } & \multicolumn{4}{|l|}{ Group } & \multirow[t]{2}{*}{$P>\mathrm{F}$} \\
\hline & Prime & Top Choice & Low Choice & Select & \\
\hline$n^{\mathrm{a}}$ & 42 & 41 & 56 & 49 & \\
\hline Like/dislike tenderness & $7.0 \pm 0.7$ & $6.8 \pm 0.8$ & $6.7 \pm 0.6$ & $7.4 \pm 0.7$ & 0.16 \\
\hline Tenderness & $7.1 \pm 1.0$ & $7.1 \pm 1.1$ & $7.0 \pm 0.9$ & $7.4 \pm 1.0$ & 0.65 \\
\hline Like/dislike flavor & $6.7 \pm 1.2 \mathrm{c}$ & $6.7 \pm 1.3 \mathrm{c}$ & $6.7 \pm 1.1 \mathrm{c}$ & $7.7 \pm 1.2 \mathrm{~b}$ & 0.01 \\
\hline Beef flavor & $6.6 \pm 0.8$ & $6.4 \pm 0.9$ & $6.6 \pm 0.8$ & $7.3 \pm 0.8$ & 0.06 \\
\hline
\end{tabular}

Within a row, means lacking a common letter (b and $\mathrm{c})$ differ $(P<0.05)$.

${ }^{\mathrm{a}} n=$ number of steaks. 
and standard errors for foodservice top loin steaks are found in Table 14. No statistical differences were found among grade groups for top loin steaks. Brooks et al. (2000) reported sensory panel ratings for tenderness, juiciness, flavor, and beef flavor did not differ across quality grades for the top loin steaks. Least squares means and standard errors for sensory panel ratings of foodservice top sirloin steaks are found in Table 15. Prime top sirloin steaks received higher $(P<0.05)$ ratings than other grades for tenderness and juiciness, which concurs with Brooks et al. (2000).

Table 14

Least squares means \pm standard errors for sensory panel ratings (like/ dislike: $10=$ like extremely, $1=$ dislike extremely; tenderness: $10=$ very tender, $1=$ not tender at all; juiciness: $10=$ very juicy, $1=$ not at all juicy; flavor: $10=$ extreme amount, $1=$ none at all) for foodservice top loin steaks

\begin{tabular}{|c|c|c|c|c|c|}
\hline \multirow[t]{2}{*}{ Sensory rating } & \multicolumn{4}{|l|}{ Group } & \multirow[t]{2}{*}{$P>\mathrm{F}$} \\
\hline & Prime & $\begin{array}{l}\text { Top } \\
\text { Choice }\end{array}$ & $\begin{array}{l}\text { Low } \\
\text { Choice }\end{array}$ & Select & \\
\hline$n^{\mathrm{a}}$ & 49 & 42 & 56 & 35 & \\
\hline $\begin{array}{l}\text { Overall like/ } \\
\text { dislike }\end{array}$ & $6.2 \pm 0.9$ & $7.0 \pm 0.9$ & $6.9 \pm 0.9$ & $7.2 \pm 1.0$ & 0.06 \\
\hline $\begin{array}{l}\text { Like/dislike } \\
\text { tenderness }\end{array}$ & $7.1 \pm 0.7$ & $7.3 \pm 0.7$ & $6.8 \pm 0.6$ & $7.3 \pm 0.7$ & 0.44 \\
\hline Tenderness & $7.1 \pm 1.0$ & $7.6 \pm 1.0$ & $7.1 \pm 1.0$ & $7.3 \pm 1.1$ & 0.42 \\
\hline Like/dislike flavor & $6.3 \pm 1.2$ & $6.9 \pm 1.2$ & $7.0 \pm 1.2$ & $7.1 \pm 1.3$ & 0.18 \\
\hline Beef flavor & $6.5 \pm 0.8$ & $6.9 \pm 0.8$ & $6.6 \pm 0.8$ & $6.9 \pm 0.9$ & 0.60 \\
\hline $\begin{array}{c}\text { Like/dislike } \\
\text { juiciness }\end{array}$ & $6.0 \pm 0.2$ & $6.7 \pm 0.2$ & $6.3 \pm 0.2$ & $6.3 \pm 0.2$ & 0.40 \\
\hline Juiciness & $5.6 \pm 0.1$ & $6.6 \pm 0.1$ & $6.1 \pm 0.1$ & $6.1 \pm 0.1$ & 0.17 \\
\hline
\end{tabular}

${ }^{\text {a }} n=$ number of steaks.

Table 15

Least squares means \pm standard errors for sensory panel ratings (like/ dislike: $10=$ like extremely, $1=$ dislike extremely; tenderness: $10=$ very tender, $1=$ not tender at all; juiciness: $10=$ very juicy, $1=$ not at all juicy; flavor: $10=$ extreme amount, $1=$ none at all) for foodservice top sirloin steaks

\begin{tabular}{|c|c|c|c|c|c|}
\hline \multirow[t]{2}{*}{ Sensory rating } & \multicolumn{4}{|l|}{ Group } & \multirow[t]{2}{*}{$P>\mathrm{F}$} \\
\hline & Prime & $\begin{array}{l}\text { Top } \\
\text { Choice }\end{array}$ & $\begin{array}{l}\text { Low } \\
\text { Choice }\end{array}$ & Select & \\
\hline$n^{\mathrm{a}}$ & 35 & 42 & 49 & 42 & \\
\hline $\begin{array}{l}\text { Overall like/ } \\
\text { dislike }\end{array}$ & $6.7 \pm 0.9$ & $6.1 \pm 0.9$ & $6.4 \pm 0.9$ & $5.8 \pm 0.9$ & 0.22 \\
\hline $\begin{array}{l}\text { Like/dislike } \\
\text { tenderness }\end{array}$ & $6.7 \pm 0.7$ & $6.0 \pm 0.7$ & $5.8 \pm 0.8$ & $5.8 \pm 0.8$ & 0.11 \\
\hline Tenderness & $7.2 \pm 1.1 \mathrm{~b}$ & $6.4 \pm 1.1 b c$ & $6.1 \pm 1.1 \mathrm{c}$ & $6.0 \pm 1.1 \mathrm{c}$ & 0.04 \\
\hline $\begin{array}{l}\text { Like/dislike } \\
\text { flavor }\end{array}$ & $6.5 \pm 1.2$ & $6.4 \pm 1.2$ & $7.0 \pm 1.3$ & $6.5 \pm 1.3$ & 0.45 \\
\hline Beef flavor & $6.8 \pm 0.8$ & $6.5 \pm 0.8$ & $6.7 \pm 0.9$ & $6.4 \pm 0.9$ & 0.63 \\
\hline $\begin{array}{c}\text { Like/dislike } \\
\text { juiciness }\end{array}$ & $6.2 \pm 0.2$ & $5.3 \pm 0.2$ & $5.5 \pm 0.2$ & $5.3 \pm 0.2$ & 0.13 \\
\hline Juiciness & $5.9 \pm 0.1 b$ & $4.8 \pm 0.1 \mathrm{c}$ & $5.3 \pm 0.1 b c$ & $4.8 \pm 0.1 \mathrm{c}$ & 0.03 \\
\hline
\end{tabular}

Within a column, means lacking a common letter (b and c) differ $(P<0.05)$.

${ }^{\text {a }} n=$ number of steaks.

\section{Discussion}

The majority of steaks evaluated in this study were considered tender. When compared to past surveys, all WBS values improved. This could be due to increased aging times, longer, slower chill rates, and more programs focused on beef tenderness. As shown in this study, approximately $47 \%$ of retail cuts are included in a packer program that could consider numerous tenderness factors including genotype and phenotype, postmortem aging times, electrical stimulation, and/or other factors influencing tenderness. This illustrates the US beef industry's continued commitment to improving beef quality and tenderness.

Because of their WBS values and consumer ratings, round retail cuts still require more attention postmortem to ensure acceptable tenderness. Decreasing the number of retail cuts that are not sufficiently aged before consumption may help to improve tenderness. Data from this survey can serve as a benchmark for tenderness of beef available at retail and foodservice levels.

\section{Acknowledgement}

Technical article from the Texas Agricultural Experiment Station. This project was funded, in part, by The Beef Checkoff.

\section{References}

Belew, J. B., Brooks, J. C., McKenna, D. R., \& Savell, J. W. (2003). Warner-Bratzler shear evaluations of 40 bovine muscles. Meat Science, 64, 507-512.

Brooks, J. C., Belew, J. B., Griffin, D. B., Gwartney, B. L., Hale, D. S., Henning, W. R., et al. (2000). National beef tenderness survey - 1998 . Journal of Animal Science, 78, 1852-1860.

Industry-Wide Cooperative Meat Identification Standards Committee. (2003). Uniform retail meat identity standards. Centennial, CO: Cattlemen's Beef Board and National Cattlemen's Beef Association.

Lorenzen, C. L., Neely, T. R., Miller, R. K., Tatum, J. D., Wise, J. W., Taylor, J. F., et al. (1999). Beef customer satisfaction: Cooking method and degree of doneness effects on the top loin steak. Journal of Animal Science, 77, 637-644.

Morgan, J. B., Savell, J. W., Hale, D. S., Miller, R. K., Griffin, D. B., Cross, H. R., et al. (1991). National beef tenderness survey. Journal of Animal Science, 69, 3274-3283.

Neely, T. R., Lorenzen, C. L., Miller, R. K., Tatum, J. D., Wise, J. W., Taylor, J. F., et al. (1998). Beef customer satisfaction: Role of cut, USDA quality grade, and city on in-home consumer ratings. Journal of Animal Science, 76, 1027-1033.

Neely, T. R., Lorenzen, C. L., Miller, R. K., Tatum, J. D., Wise, J. W., Taylor, J. F., et al. (1999). Beef customer satisfaction: Cooking method and degree of doneness effects on the top round steak. Journal of Animal Science, 77, 653-660.

Savell, J. W., Lorenzen, C. L., Neely, T. R., Miller, R. K., Tatum, J. D., Wise, J. W., et al. (1999). Beef customer satisfaction: Cooking method and degree of doneness effects on the top sirloin steak. Journal of Animal Science, 77, 645-652.

Shackelford, S. D., Morgan, J. B., Savell, J. W., \& Cross, H. R. (1991). Identification of threshold levels for Warner-Bratzler shear force in top loin steaks. Journal of Muscle Foods, 2, 289-296. 
USDA (1996). Institutional meat purchase specifications for fresh beef products: Series 100. Washington, DC: United States Department of Agriculture, Agricultural Marketing Service. Available at: http:// www.ams.usda.gov/lsg/imps100.pdf. Accessed 06.11.03.
USDA (1997). United States standards for grades of carcass beef. Washington, DC: United States Department of Agriculture, Agricultural Marketing Service. Available at: http://www.ams.usda.gov/lsg/ stand/standards/beef-car.pdf. Accessed 28.03.07. 